on Nosocomial and Healthcare-Associated Infections. Infect Control Hosp Epidemiol 2000;21:742-744.

10. Perl TM, Golub JE. New approaches to reduce Staphylococcus aureus nosocomial infection rates: treating $S$ aureus nasal carriage. Ann Pharmacother 1998;32(suppl):S7-S16.

11. Wenzel RP, Perl TM. The significance of nasal carriage of Staphylococcus aureus and the incidence of postoperative wound infection. I Hosp Infect 1995;31:13-24.

12. Boyce JM. Preventing staphylococcal infections by eradicating nasal carriage of Staphylococcus aureus: proceeding with caution. Infect Control Hosp Epidemiol 1996;17:775-779.

13. Brown P, Davies DT, O'Hanlon PJ, Wilson JM. The chemistry of Pseudomonic acid, 15: synthesis and antibacterial activity of a series of 5-alkyl, 5-alkenyl, and 5-heterosubstituted oxazoles. J Med Chem 1996;39:446-457.

14. Perl TM, Cullen JJ, Pfaller MA, Wenzel RP, Zimmerman B, Herwaldt LA, et al. A randomized, double-blind, placebo-controlled clinical trial of intranasal mupirocin to prevent $S$ aureus nosocomial infections. Infect
Control Hosp Epidemiol 1999;20:282. Abstract 45.

15. Kluytmans J. Reduction of surgical site infections in major surgery by elimination of nasal carriage of Staphylococcus aureus. J Hosp Infect 1998;40(suppl B):S25-S29.

16. Doebbeling BN, Breneman DL, Neu HC, Aly R, Yangco BG, Holley HP $\mathrm{Jr}$, et al. Elimination of Staphylococcus aureus nasal carriage in health care workers: analysis of six clinical trials with calcium mupirocin ointment. The Mupirocin Collaborative Study Group. Clin Infect Dis 1993;17:466-474.

17. Boelaert IR. Staphylococcus aureus infection in haemodialysis patients. Mupirocin as a topical strategy against nasal carriage: a review. $J$ Chemother 1994;6(suppl 2):S19-S24.

18. Henkel T, Finlay J. Emergence of resistance during mupirocin treatment: is it a problem in clinical practice? J Chemother 1999;11:331-337.

19. Miller MA, Dascal A, Portnoy J, Mendelson J. Development of mupirocin resistance among methicillin-resistant Staphylococcus aureus after widespread use of nasal mupirocin ointment. Infect Control Hosp Epidemiol 1996;17:811-813.

\title{
Rapid Extraction and Direct Identification of Methicillin-Resistant Staphylococci in Clinical Samples Using PCR
}

Gina Pugliese, RN, MS

Martin S. Favero, PhD

Methicillin-resistant staphylococci (MRS) are one of the most common causes of nosocomial infections and bacteremia. Standard bacterial identification and susceptibility testing frequently require as long as 72 hours to report results, and there may be difficulty in rapidly and accurately identifying methicillin resistance. The use of polymerase chain reaction (PCR) is a rapid and simple process for the amplification of target DNA sequences, which can be used to identify and test bacteria for antimicrobial resistance. However, many sample preparation methods are unsuitable for PCR utilization in the clinical laboratory, because they either are not cost-effective, take too long to perform, or do not provide a satisfactory DNA template for PCR. Jaffe and coinvestigators from David Grant Medical Center, Travis AFB, California, conducted tests whose goal was to provide same-day results to facilitate rapid diagnosis and therapy. In this report, they describe a rapid method for extraction of bacterial DNA directly from blood-culture bottles that gave quality DNA for PCR in as little as 20 minutes. They compared this extraction method to the standard QIAGEN method for turnaround time (TAT), cost, purity, and use of template in PCR.

Specific identification of MRS was determined using intragenic primer sets for bacterial and Staphylococcus 16S rRNA and mecA gene sequences. The PCR primer sets were validated with 416 isolates of staphylococci, including methicillinresistant Staphylococcus aureus $(\mathrm{n}=106)$, methicillin-sensitive $S$ aureus ( $\mathrm{n}=134)$, and coagulase-negative Staphylococcus $(\mathrm{n}=176)$. The total supply cost of the extraction method and PCR was $\$ 2.15$ per sample, with a result TAT of less than 4 hours. The methods represent a rapid and accurate DNA extraction and PCR-based identification system, which makes the system an ideal candidate for use under austere field conditions and one that may have utility in the clinical laboratory.

FROM: Jaffe RI, Lane JD, Albury SV, Niemeyer DM. Rapid extraction from and direct identification in clinical samples of methicillin-resistant staphylococci using the PCR. J Clin Microbiol 2000;38:3407-3412. 